\title{
Meningkatkan Kinerja Aparatur Sipil Negara dalam Melayani Masyarakat
}

\author{
AHMAD FAUZI \\ Widyaiswara Ahli Madya BPSDM Provinsi Rau \\ Jl. Ronggowarsito No 14 Pekanbaru \\ E-mail : ahmadfauziwi@gmail.com
}

\begin{abstract}
Penelitian ini dilatarbelakangi belum optimalnya kinerja ASN dalam memberikan pelayanan kepada masyarakat. Melalui pendekatan metode penelitian deskriptif. Data primer diperoleh langsung melalui kuesioner kepada Aparatur Sipil Negara di Kecamatan yang berjumlah 56 orang dan data diolah secara deskriptif. Hasil penelitian menunjukkan bahwa kinerja pegawai yang masih belum optimal disebabkan oleh berbagai hal diantaranyanya adalah budaya disiplin dalam bekerja dan juga masalah insentif serta kompetensi daripada ASN dalam bekerja.
\end{abstract}

Keywords: Kinerja ASN

Aparatur sipil negara (ASN) sebagai aparatur negara mempunyai posisi sangat strategis dan peranan menentukan dalam menyelenggarakan pemerintahan dan pembangunan. Sebagai aparatur negara, ASN berkewajiban menyelenggarakan tugas pemerintahan dan pembangunan dengan penuh kesetiaan dan ketaatan kepada Pancasila. Undang-undang Dasar 1945, negara dan pemerintah. Untuk itu, ASN sebagai pelaksana perundangundangan di dalam melaksanakan tugas kedinasan. Pemberian tugas kedinasan kepada ASN pada dasarnya merupakan kepercayaan dari atasan yang berwenang, dengan harapan bahwa tugas itu akan dilaksanakan dengan sebaik-baiknya. Oleh karena itu, setiap ASN wajib melaksanakan tugas kedinasan yang dipercayakan kepada dengan penuh pengabdian, kesadaran, dan penuh tanggung jawab.

Aparatur kecamatan merupakan sumber daya manusia yang bertugas di tingkat kecamatan dan menjadi ujung tombak pelayanan kepada masyarakat. ASN ini menjadi barometer pelayanan kepada masyarakat, dimana saat ini kinerja pemerintah sangat menjadi perhatian masyarakat dan ini merupakan tanggung jawab dari pemerintah dalam memberikan pelayanan yang berkualitas.

Begitu besarnya beban ASN kecamatan dalam memberikan pelayanan kepada masyarakat menjadikan pemerintah mengeluarkan kota Pekanbaru mengeluarkan kebijakan mengenai tunjangan tambahan penghasilan sebagai bentuk kompensasi dari pemerintah kepada ASN yang memiliki kedisiplinan dan prestasi dalam bekerja

Kinerja merupakan singkatan dari kinetika energi kerja yang padanannya dalam bahasa inggris adalah performance. Istilah performance menurut Wirawan (2010: 5) sering di Indonesia kan sebagai performa. Kinerja adalah keluaran yang dihasilkan oleh fungsi-fungsi atau indikator-indikator suatu pekerjaan atau suatu profesi dalam waktu tertentu. Pekerjaan adalah aktivitas menyelesaikan sesuatu atau membuat sesuatu yang hanya memerlukan tenaga dan keterampilan tertentu seperti yang dilakukan oleh pekerja kasar.

Kemudian pendapat lain mengenai kinerja menurut Pabundu (2010: 121) sebagai hasil-hasil fungsi pekerjaan/kegiatan seseorang atau kelompok dalam suatu organisasi yang dipengaruhi oleh berbagai faktor untuk mencapai tujuan organisasi dalam periode waktu tertentu. Fungsi pekerjaan atau kegiatan yang dimaksudkan di sini adalah pelaksanaan hasil pekerjaan atau kegiatan seseorang atau kelompok yang menjadi 
wewenang dan tanggung jawabnya dalam suatu organisasi.

Selain itu, menurut Sutrisno (2010: 191) kinerja juga didefinisikan sebagai kesuksesan seseorang di dalam melaksanakan suatu pekerjaan dan berupa hasil kerja yang dapat dicapai seseorang atau sekelompok orang dalam suatu organisasi sesuai dengan wewenang dan tanggung jawab masing-masing dalam rangka upaya mencapai tujuan organisasi bersangkutan secara legal, tidak melanggar hukum dan sesuai dengan moral maupun etika.

Pengertian lain mengenai kinerja menurut Anoraga (2005: 50) adalah suatu tingkah laku sebagai keluaran (output) dari suatu proses berbagai macam komponen kejiwaan yang melatarbelakanginya atau menghasilkan lebih banyak, dan berkualitas lebih baik, dengan usaha yang sama.

Terakhir menurut Siagian (2013: 224) penilaian kinerja perlu dilakukan secara formal berdasarkan kriteria yang ditetapkan secara objektif serta didokumentasikan secara sistematik. Jadi penilaian kinerja ini diperlukan untuk menentukan tingkat kontribusi individu terhadap pencapaian kinerja organisasi.

Pentingnya kinerja berkaitan dengan capaian yang dihasilkan oleh individu dalam bekerja dan pada akhirnya akan mempengaruhi capaian organisasi dalam mencapai tujuan yang lebih besar. Hal ini sebagaimana disampaikan oleh Sutrisno (2010: 191) bahwa organisasi mempunyai tujuan dengan hidup melalui aktivitas yang dilakukan oleh para karyawannya sesuai dengan unit kerja maka masing-masing unit dinilai kinerjanya agar kinerja sumber daya manusia yang terdapat dalam unit dapat dinilai secara objektif untuk itu seorang manajer perlu memiliki ukuran kinerja seorang karyawan jangan sampai menunggu timbulnya suatu masalah. Di samping itu informasi tentang kinerja karyawan diperlukan pula bila suatu saat seorang manajer ingin merubah sistem yang ada. Kita sering terjebak untuk menilai seseorang berkinerja buruk padahal sistem yang digunakan salah.

Pentingnya pengukiran kinerja karyawan dalam rangka meningkatkan motivasi dan gairah berprestasi pada masa-masa berikutnya juga berkaitan dengan masalah karir dan penggajian karyawan. Menurut Cormick dalam Sutrisno (2010: 191) kinerja adalah kuantitas, kualitas, dan waktu yang digunakan dalam menjalankan tugas. Kuantitas adalah hasil yang dapat dihitung sejauhmana seseorang dapat berhasil mencapai tujuan yang telah ditetapkan. Kualitas adalah bagaimana seseorang dalam menjalankan tugasnya, yaitu mengenai banyaknya kesalahan yang dibuat, kedisiplinan dan ketepatan. Waktu kerja adalah mengenai jumlah abesen yang dilakukan, keterlambatan dan lamanya masa kerja dalam tahun yang telah dijalankan.

Sedangkan menurut Miner dalam Sutrisno (2010: 172) empat aspek dari kinerja adalah kualitas, kuantitas, waktu kerja dan kerjasama.

1. Kuantitas, berkenaan dengan berapa jumlah produk atau jasa yang dapat dihasilkan.

2. Kualitas, menerangkan tentang jumlah kesalahan waktu dan ketepatan dalam melakukan tugas.

3. Waktu kerja, menerangkan akan berapa jumlah absen keterlambatan serta masa kerja yang telah dijalani individu pegawai tersebut.

4. Kerjasama, menerangkan bagaimana indivdiu membantu atau menghambat usaha dari teman sekerjanya.

Dari tiga pendapat yakni pendapat Cormick, Minner dan Hamzah mengenai dimensi kinerja dapat disintesiskan bahwa dimensi kinerja antara lain: Kualitas, kuantitas, waktu kerja, kerjasama, iniatif, kemampuan kerja dan komunikasi. Kemudian Minner dalam Sutrisno (2010: 172) menemukan faktor-faktor yang mempengaruhi kinerja seseorang antara lain: 
1. Sikap yaitu meliputi keyakinan, perasaan, dan perilaku yang cenderung kepada orang lain atau sesuatu.

2. Keterlibatan kerja yaitu tingkat seseorang memilih berpartisipasi secara aktif dalam bekerja, menjadikan kerja sebagai pusat perhatian hidup dan memandang pekerjaan sebagai sesuatu yang penting kepada penghargaan diri.

3. Perilaku yaitu tindakan seseorang dalam keadaan umum dan khusus

4. Partisipasi yaitu tingkat seseorang secara nyata ikut serta dalam kegiatan-kegiatan organisasi.

5. Penampilan yaitu tindakan individu yang membantu mencapai tujuan organisasi termasuk kuantitas dan kualitas.

Sedangkan menurut Pabundu (2010:

121), faktor-faktor yang berpengaruh terhadap kinerja terdiri dari faktor intern dan ekstern. Faktor intern yang mempengaruhi kinerja karyawan terdiri dari kecerdasan, ketrampilan, kestabilan emosi, motivasi, persepsi peran, kondisi keluarga, kondisi fisik seseorang dan karakteristik kelompok kerja dan sebagainya. Sedangkan pengaruh eksternal antara lain berupa peraturan ketenagakerjaan, keinginan pelanggan, pesaing, nilai-nilai sosial, buruk, kondisi ekonomi, perubahan lokasi kerja dan kondisi pasar.

Selain itu menurut Wirawan (2010: 7) kinerja pegawai merupakan hasil sinergi dari sejumlah faktor, antara lain:

1) faktor internal karyawan, yaitu faktor-faktor dari dalam diri pegawai yang merupakan faktor bawaan dari lahir dan faktor yang diperoleh ketika ia berkembang misalnya bakat, sifat pribadi, serta keadaan fisik dan kejiwaan. Sementara itu faktorfaktor yang diperoleh misalnya pengetahuan, ketrampilan, etos kerja, pengalaman kerja dan motivasi kerja. Setelah dipengaruhi oleh lingkungan internal organisasi dan faktor lingkungan eksternal faktor lingkungan internal ini mempengaruhi kinerja pegawai. Jadi dapat diasumsikan bahwa makin tinggi faktor-faktor internal tersebut, makin tinggi pula kinerja pegawai. Sebaliknya makin rendah faktor tersebut makin rendah pula kinerjanya. 2) faktor-faktor lingkungan internal organisasi, dalam melaksanakan tugasnya, pegawai memerlukan dukungan organisasi tempat ia bekerja. Dukungan tersebut sangat mempengaruhi tinggi rendahnya kinerja pegawai, misalnya strategi organisasi, dukungan sumber daya yang diperlukan untuk melaksanakan pekerjaan serta sistem manajemen dan kompensasi. Oleh karena itu manajemen organisasi harus menciptakan lingkungan internal organisasi yang kondusif sehingga dapat mendukung dan meningkatkan produktivitas karyawan. 3) faktor lingkungan eksternal organisasi, faktorfaktor lingkungan eksternal organisasi adalah keadaan, kejadian, atau situasi yang terjadi di lingkungan eksternal organisasi yang mempengaruhi kinerja karyawan. Budaya masyarakat juga merupakan faktor eksternal yang mempengaruhi kinerja karyawan. Misalnya alon-alon asal kelakon dan mangan ora mangan asal kumpul mempengaruhi kinerja manusia Indonesia.

Kemudian menurut Mathis dan Jackson (2001: 82) banyak faktor yang mempengaruhi kinerja dari individu tenaga kerja antara lain kemampuan mereka, motivasi, dukungan yang diterima, keberadaan pekerjaan yang mereka lakukan dan hubungan atau kebersamaan mereka dengan organisasi.

Selanjutnya Burn dan Lerner (1984: 2) juga menjelaskan konsep diri mempengaruhi kinerja bahwa gambaran konsep diri sebuah kunci peran sebagai faktor dalam integrasi kepribadian, dalam perilaku motivasi dan dalam menerima mental yang sehat. Konsep diri dalam setiap individu diperlukan hal ini karena kebutuhan dasar manusia untuk mendapat penghargaan secara positif baik dari seseorang maupun dari sekelompok 
manusia. Konsep diri terbentuk karena seseorang berinteraksi dengan lingkungan sosialnya dan selanjutnya dapat mempengaruhi perilakunya dalam berkinerja.

Penghasilan dan tambahan penghasilan sebagai entuk motivasi dari pegawai dalam bekerja serta kompetensi yang memang merupakan persyaratan dalam bekerja memiliki pengaruh positif terhadap kinerja pegawai.

\section{METODE}

Penelitian ini menggunakan jenis penelitian survey dengan pedekatan deskriptif. Lokasi penelitian ini dilakukan pada Propinsi Riau khususnya pelayanan ASN dalam memberikan pelayanan kepada masyarakat. Sampel diambil sebanyak 56 orang dengan menggunakan metode area sampling. Jenis dan sumber data atau materi yang diperlukan dalam penelitian ini antara lain meliputi data primer dan skunder. Untuk mendapatkan data dan informasi serta bahanbahan lainnya yang diperlukan dan berhubungan dengan penelitian ini, maka teknik pengumpulan data dilakukan dengan cara kuesioner dan wawancara. Untuk menjawab permasalahan dan pertanyaan penelitian, maka metode analisis data yang digunakan adalah deskriptif. (Suroto, dkk (2017).

\section{HASIL}

Berdasarkan hasil penelitian berkaitan dengan masalah kinerja ASN yang dikaitkan dengan kinerja ASN dalam melayani Kinerja adalah keluaran yang dihasilkan oleh fungsifungsi atau indikator-indikator suatu pekerjaan atau suatu profesi dalam waktu tertentu. Empat aspek dari kinerja adalah kualitas, kuantitas, waktu kerja dan kerjasama.

Kualitas kerja pegawai masuk dalam kategori baik dimana dari tiga indikator dapat diketahui indiktor tertinggi adalah pada waktu kerja secara tersedia dengan baik dalam melayani masyarakat dan indikator terendah adalah pada kesalahan dalam bekerja selalu. Pegawai dalam bekerja masih mendapatkan berbagai kesalahan seperti kesalahan dalam mengetik dan juga terhadap dokumen yang tercecer serta masalah persyaratan yang harus masyarakat berulang kali datang ke kantor dalam melengkapi persyaratan yang dibutuhkan dalam pelayanan. Hal ini membuat masyarakat memberikan keluhannya kepada petugas pelayanan dan juga inefisiensi dalam memberikan pelayanan juga menjadi keluhan dari masyarakat.

Kualitas kerja pegawai masuk dalam kategori baik dimana dari tiga indikator dapat diketahui indiktor tertinggi adalah pada target kerja yang harus diselesaikan dalam satu waktu dapat dengan baik diselesaikan dan indikator terendah adalah pada kebutuhan masyarakat dalam pelayanan sudah selesai dikerjakan. Hal ini disebabkan karena sebagian masyarakat merasa pelayanan yang diberikan pihak kecamatan dan perangkatnya kepada masyarakat masih belum optimal dan masih belum sepenuh hati. Pelayanan yang ditunda-tunda masih dirasakan oleh masyarakat. Sehingga apa yang diharapkan masyarakat dalam pelayanan masih belum didapatkan. Kemudian juga berkaitan dengan kebutuhan masyarakat dalam pelayanan yang fleksibel pada waktu tertentu misalnya petugas meluangkan waktu yang lebih masih belum dirasakan.

Waktu kerja pegawai dalam kategori baik dimana dari tiga indikator dapat diketahui indiktor tertinggi adalah pada kedisiplinan memanfaatkan waktu kerja untuk melayani masyarakat dan indikator terendah adalah pada pegawai memiliki masa kerja yang memadai dalam melayani masyarakat. Masa kerja menjadi persoalan seperti pada saat pelayanan setelah siang hari. Terkadang masyarakat memiliki waktu untuk berurusan setelah waktu istirahat karena bekerja, namun petugas selalu menangguhkan pelayanan pada siang hari ke hari berikutnya dengan berbagai alasan, misalnya antrian sudah habis dan juga masalah kekurangan petugas.

Kerjasama pegawai masuk dalam kategori baik dimana dari tiga indikator 
dapat diketahui indiktor tertinggi adalah pada dilakukan pengawasan dari atasan secara berkesinambungan dalam memberikan pelayanan kepada masyarakat dan indikator terendah adalah pada pelayanan diberikan dengan sistem team work. Pelayanan kepada masyarakat masih belum sepenuhnya dapat dilayani oleh petugas lain, walaupun petugas penggantinya ada, hal ini membuat pelayanan menjadi kurang efisien.

\section{PEMBAHASAN}

Kinerja ASN dalam kategori baik. Ini menunjukkan bahwa kinerja pegawai sudah kategori baik, dari empat indikator kinerja dapat diketahui indikator tertinggi adalah pada kuantitas dan kerjasama yang dibangun oleh pegawai dalam bekerja kepada masyarakat. Sedangkan indikator terendah adalah pada kualitas kerja yang dihasilkan oleh pegawai dalam melayani masyarakat. Masalah pada kualitas pelayanan kesalahan dalam bekerja selalu terjadi. Pegawai dalam bekerja masih mendapatkan berbagai kesalahan seperti kesalahan dalam mengetik dan juga terhadap dokumen yang tercecer serta masalah persyaratan yang harus masyarakat berulang kali datang ke kantor dalam melengkapi persyaratan yang dibutuhkan dalam pelayanan. Hal ini membuat masyarakat memberikan keluhannya kepada petugas pelayanan dan juga inefisiensi dalam memberikan pelayanan juga menjadi keluhan dari masyarakat.

Terdapat banyak faktor yang mempengaruhi kinerja diantaranya sebagaimana dijelaskan oleh Widyatmini, W., \& Hakim, L. (2011) menunjukkan kepemimpinan, kompetensi, dan kompensasi sangat signifikan mempengaruhi kinerja pegawai. Juga dijelaskan oleh Wirotomo, D., \& Pasaribu, P. N. (2015) menyatakan bahwa secara parsial kompetensi berpengaruh positif dan signifikan terhadap kinerja pegawai. Menurut Setiawan, M., Unde, A. A., \& Farid, M. (2016) bahwa kompetensi Komunikasi berpengaruh terhadap kinerja aparatur dan juga Nadir, M. (2017) bahwa Budaya Organisasi yang terdiri dari ketentuan-ketentuan, nilai, Philosophy, iklim organisasi dapat berdampak pada Komitmen organisasional Aparatur Sipil Negara (ASN) di Pemerintah Provinsi Sulawesi Barat terhadap komitmen organisasional yang pada akhirnya dapat meningkatkan kinerja mereka.

\section{SIMPULAN}

Dari uraian di atas, maka dapat disimpulkan bahwa belum optimalnya kinerja ASN dalam memberikan pelayanan kepada masyarakat khususnya di kecamatan dapat ditingkatkan melalui pemberian pelatihan dalam bentuk dan dalam rangka pengembangan ASN. Materi tentang peningkatan kompetensi kerja dan juga membentuk budaya kerja yang produktif serta dukungan pemerintah akan memberikan dorongan besar dalam rangka peningkatan kinerja ASN ke depan.

\section{DAFTAR RUJUKAN}

Anoraga. 2005. Psikologi Kerja, Rineka Cipta, Jakarta.

Suroto, B., Novita, N., Pailis, E. A., Waldelmi, I., \& Fatkhurahman, F. (2017). Metode Penelitian Tindakan Solusi Bagi Masalah Sosial. Jurnal Diklat Review, 1(1), 25-28.

Mathis dan Jackson, 2001. Manajemen Sumber Daya Manusia, Salemba Empat. Jakarta.

Nadir, M. (2017). Pengaruh Servant Leadership, Karakteristik Individu, Budaya Organisasi terhadap Komitmen Organisasional dan Kinerja Aparatur Sipil Negara pada Pemerintah Provinsi Sulawesi Barat. Pepatudzu: Media Pendidikan dan Sosial Kemasyarakatan, 12(1), 38-50. 
Pabundu Tika. 2010. Budaya Organisasi dan Peningkatan Kinerja Perusahaan. PT. Bumi Aksara.

Setiawan, M., Unde, A. A., \& Farid, M. (2016). Kompetensi Komunikasi Aparatur Sipil Negara terhadap Kinerja dalam Budaya Organisasi pada Badan Kepegawaian Daerah Kabupaten Biak Numfor. KAREBA: Jurnal Ilmu Komunikasi, 3(4), 243248.

Siagian, 2013, Fungsi-fungsi Manajerial. Jakarta: Bumi Aksara.

Sutrisno. 2010. Manajemen Sumber Daya Manusia. Edisi Pertama. Cetakan. Pertama.

Widyatmini, W., \& Hakim, L. (2011). Hubungan kepemimpinan, kompensasi dan kompetensi terhadap kinerja pegawai dinas kesehatan kota depok. Jurnal Ilmiah Ekonomi Bisnis, 13(2).

Wirawan. Evaluasi Kinerja Sumber Daya Manusia, Teori Aplikasi dan Penelitian (Jakarta: Salemba Empat, 2012) h. 5.

Wirotomo, D., \& Pasaribu, P. N. (2015). Pengaruh Kompetensi, Pengembangan Karir, Pendidikan Dan Pelatihan (Diklat) Terhadap Knerja Pegawai Direktorat Jenderal Perimbangan Keuangan. MIX: Jurnal Ilmiah Manajemen, 5(3). 